Techniques \& Culture

Revue semestrielle d'anthropologie des techniques

17-18| 1992

Préhistoire et ethnologie, le geste retrouvé

\title{
Présentation
}

\section{Claudine Karlin}

\section{OpenEdition}

Journals

Édition électronique

URL : https://journals.openedition.org/tc/682

DOI : $10.4000 /$ tc.682

ISSN : 1952-420X

Éditeur

Éditions de l'EHESS

Édition imprimée

Date de publication : 1 novembre 1992

ISSN : 0248-6016

Référence électronique

Claudine Karlin, «Présentation », Techniques \& Culture [En ligne], 17-18| 1992, mis en ligne le 10 janvier 2006, consulté le 29 septembre 2022. URL : http://journals.openedition.org/tc/682 ; DOI : https:// doi.org/10.4000/tc.682

Ce document a été généré automatiquement le 29 septembre 2022.

Tous droits réservés 


\section{Présentation}

Claudine Karlin 